\title{
Forest-Range Inventory: A Multiple-Use Survey
}

\section{HENRY A. PEARSON AND HERBERT $S$. STERNITZKE}

Highlight: Successful attempts to incorporate understory herbage and browse measurements into the nationwide Forest Survey are described and evaluated. These attempts were initiated to inventory multiple forest resources-timber, range, wildlife habitaton a regular basis requiring minimum time and environmental disturbance.

The need for a definitive study of the nation's range resources has been recognized by range scientists. As recently as 1970, a Forest Service committee of research administrators endorsed the need for statistically designed ground surveys for scientific inventory and analysis of range resources (Blaisdell et al., 1970).

The authors are principal range scientist (Pineville, La.) and principal resource analyst (New Orleans, La.) of the Southern Forest Experiment Station, U.S. Department of Agriculture, Forest Service.

The authors gratefully acknowledge the assistance of Harold E. Grelen, range scientist, Southern Forest Experiment Station, who instructed on plant identification, and Louie B. Whitaker, range technician, Southern Forest Experiment Station, who conducted field follow-up training and quality control of the Forest Survey teams.

Manuscript received January 30, 1974.
Within the research branch of the Forest Service, the "Forest Survey" has been delegated nationwide responsibility for the collection and analysis of resource information from forest and forest-related lands. Authority for this activity is contained in the McSweeny-McNary Forest Research Act of 1928 and subsequent amendments. To date, this authority has been exercised only with respect to timber and wood products. Research Work Units, headquartered at various experiment stations throughout the country, have the responsibility for carrying out the functions of the Forest Survey. At the Southern Forest Experiment Station, for example, the Forest Survey is an assignment of the Forest Resources Research Work Unit.

Early in 1973, the Forest Resources and the Range Management Research Work Units of the Southern Station initiated a large-scale field test in 11 parishes (counties) of southwest Louisiana. With a land area of nearly 7 million acres on the Gulf Coastal Plain, the region encompasses most of the longleaf pine-bluestem ecosystem west of the Mississippi. The ecosystem is probably unexcelled in its ability to produce forage and timber simultaneously.
The objectives of this initial study were (1) to devisc appropriate range methods and sampling procedures that could be incorporated into the existing field design of the Forest Survey, and (2) to relate timber resource classifications of the nationwide Forest Survey to associated range conditions. The ultimate objective will be to inventory the region's forest and rangeland resources in southwest Louisiana. This paper describes the methods, rationale, and reliability of integrated forestrange inventories conducted by the Forest Survey in the South.

\section{Methods and Rationale}

Advantages in programming the Forest Survey as a vehicle for conducting range inventories include regular measurement intervals that provide precise trend information; a holistic look at understory-overstory forest potentials-timber, range, wildlife habitat; and use of the Forest Survey organization's expertise to administer the project.

To be usable by the Forest Survey in the South, range methods need to be essentially workable year-round; cause no disturbance of vegetation or site; require not more than approximately $1 / 2$-hour per sample location 
for data collection; and employ classifications that can be applied by juniorgrade professional foresters.

Forest Survey ground sample locations are permanently established at 3-mile grid intersections throughout each state. At each forested location, 10 sample points are systematically distributed on an area of about 1 acre and specified timber resource data recorded. Circular $9.6 \mathrm{ft}^{2}$-range plots (Campbell and Cassady, 1949) are located $10 \mathrm{ft}$ north of points numbered $3,5,7$, and 9 of the timber survey samples and marked with small center stakes. The four range sample plots at each location are arranged in a diamond-shaped pattern $114.3 \mathrm{ft}$ apart.

\section{Foliage cover}

Plant cover is the best single measure of environmental impacts on understory vegetation (Morris, 1973). It can be used to describe responses due to fire, logging, grazing, overstory,

Table 1. Chi-square evaluations ${ }^{1}$ for range resources quality control of Forest Survey after elimination of constant and linear bias when tested at the $5 \%$ level of significance.

\begin{tabular}{|c|c|c|c|c|c|c|c|c|c|c|}
\hline \multirow[b]{2}{*}{ Measurement } & \multicolumn{10}{|c|}{ Observer } \\
\hline & 1 & 2 & 3 & 4 & 5 & 6 & 7 & 8 & 9 & 10 \\
\hline \multicolumn{11}{|l|}{ Herbage cover } \\
\hline \multicolumn{11}{|l|}{ Browse cover } \\
\hline \multicolumn{11}{|l|}{ Herbage indicator species ${ }^{2}$} \\
\hline Andropogon tener (I) & & & & & * & $*$ & & & & \\
\hline \multicolumn{11}{|l|}{ A. virginicus (U) } \\
\hline Other Andropogon (D) & & & & & & & $*$ & & & \\
\hline \multicolumn{11}{|l|}{ Uniola spp. (D) } \\
\hline Panicum spp. (I) & $*$ & & & & $*$ & $*$ & $*$ & & & \\
\hline \multicolumn{11}{|l|}{ Muhlenbergia expansa $(\mathrm{D}, \mathrm{U})$} \\
\hline Axonopus affinis (U) & & & & $*$ & & $*$ & & & & \\
\hline Aristida spp. (U) & & & & & & $*$ & & & & \\
\hline Other grass (I) & $*$ & & & & & $*$ & $*$ & $*$ & & \\
\hline Grasslike (I) & & & $*$ & & & & & & & \\
\hline \multicolumn{11}{|l|}{ Legume (I) } \\
\hline Other forbs (U) & & & $*$ & & & & & & & \\
\hline \multicolumn{11}{|l|}{ Browse indicator species ${ }^{3}$} \\
\hline \multicolumn{11}{|l|}{ Ilex vomitoria (D) } \\
\hline \multicolumn{11}{|l|}{ Callicarpa americana (D) } \\
\hline \multicolumn{11}{|l|}{ Vaccinium elliottii (D) } \\
\hline Myrica cerifera L. (U) & & & & & & & $*$ & & & \\
\hline Rhus spp. (U) & & & * & & & & & & & \\
\hline \multicolumn{11}{|l|}{$\begin{array}{l}\text { Rhus spp. (U) } \\
\text { Cornus spp. (D) }\end{array}$} \\
\hline \multicolumn{11}{|l|}{ Crataegus spp. (M) } \\
\hline \multicolumn{11}{|l|}{ Quercus spp. (U) } \\
\hline Other shrubs \& trees $(\mathrm{M})$ & $*$ & & $*$ & & $*$ & & & & & \\
\hline \multicolumn{11}{|l|}{ Rubus spp. (M,U) } \\
\hline \multicolumn{11}{|l|}{ Smilax spp. (D) } \\
\hline Other vines (D) & $*$ & & & & $*$ & & & & & \\
\hline \multicolumn{11}{|l|}{ Pine reproduction } \\
\hline \multicolumn{11}{|l|}{ Herbage condition } \\
\hline \multicolumn{11}{|l|}{ Browse condition } \\
\hline \multicolumn{11}{|l|}{ Burning } \\
\hline \multicolumn{11}{|l|}{ Livestock } \\
\hline \multicolumn{11}{|l|}{ Herbage use } \\
\hline Browse use & & & & & & & & & & \\
\hline
\end{tabular}

\footnotetext{
${ }^{1}$ Asterisks denote statistical significance.

${ }^{2}$ Letters in parenthesis refer to herbage value rating: D-decreaser, I-increaser, and $U-$ unaffected.

${ }^{3}$ Letters in parenthesis refer to browse value rating: $\mathrm{D}$-desirable, $\mathrm{M}$-moderately desirable, and $U$-undesirable.
}

1-day's training could measure foliage cover by ocular estimate as accurately as with the point-frame method.

\section{Indicator species}

B otanical composition indicates management history (Grelen and Duvall, 1966). Threeawns (Aristida spp.), for example, are symptomatic of heavy grazing or other disturbance on dry sites; carpetgrass (Axonopus affinis Chase) indicates heavy grazing on moist sites.

Plants were estimated by $25 \%$ botanical composition categories. Forest Survey personnel classified 20 different species or species groups. All other species were categorized in one of four classes: "other" grasses, forbs, vines, or shrubs. When indicator species in grouped categories exceeded $25 \%$ of the botanical composition, dominant species were listed in the remarks section of the field form.

To determine botanical composition, indicator species with more than $25 \%$ were assigned the low percentage of each category, for instance, 25, 50, and $75 \%$. For species having less than $25 \%$ of the botanical composition, percentagcs were calculated:

Percent $=$

100 - (Sum of percentages greater than 25\%)

Number of species with less than $25 \%$

\section{Forest-range condition}

Range condition refers to the state and health of the range. It is judged in terms of what the range is naturally capable of producing. Separate herbage and browse classifications appear appropriate for forest-ranges in the South. Herbage condition was defined as a current departure of the herbaceous vegetation composition from the ecological potential that a forest-range ecosystem is capable of supporting when grazing is excluded. Browse condition was similarly defined in terms of "desirable browse." It is recognized that in traditional range condition classifications, browse plants are generally considered invaders.

Plants either increase in relative coverage with heavy grazing, decrcasc after a period of increase, or decrease immediately until ultimately eliminated (Dyksterhuis, 1949). Consequently, herbage was categorized as unaffected, increaser, or decreaser plants. Unaffected plants also include species that are essentially not affected by heavy grazing. Browse was assessed similarly to herbage, but categories designated desirability for animal consumption: desirable, moderately desirable, and undesirable. Desirability and ecological ranking are generally synonymous. 
Plots were evaluated according to five forest-range condition classes: (1) excellent-more than $75 \%$ botanical composition composed of the sum of all decreaser herbage or desirable browse percentages and "allowable" percentages for increasers or moderately desirable browse, (2) good-51$75 \%$, (3) fair-26-50\%, (4) poor-10$25 \%$, and (5) very poor-less than $10 \%$. The "allowable" percentage was $5 \%$ each since increaser herbage or moderately desirable browse groups include individual species varying in ecological importance. The exception was slender bluestem (Andropogon tener (Nees) Kunth), which was $15 \%$. Unaffected herbage and undesirable browse were not considered in condition determinations.

\section{Pine reproduction}

Pine reproduction (trees less than 1.0 inch dbh.) was recorded on each plot by the dominant-number or vigor-species (longleaf, slash, loblolly, shortleaf, or other pine). These measurements indicate the effects of grazing and timber management on pine seedling establishment.

Burning history, livestock presence, and utilization

Observed disturbances on each sample location were classified for burning history, livestock presence, and intensity of forage utilization. In the determination of utilization intensity, herbage and browse components were individually examined. Categories included:

Light.-Difficult to find grazed plants. Grazing patchy and generally less than $35 \%$ of the plants grazed.

Moderate.-Frequently find grazed plants but ungrazed plants are present. Generally 35 to $70 \%$ of the plants are grazed. Carpetgrass may be relatively abundant; if so, seedstalks are usually noticeable and average stubble heights are more than 4 inches.

Heavy.-Generally more than $70 \%$ of the plants are grazed. Carpetgrass may be relatively abundant; if so, seedstalks are conspicuously absent and carpetgrass gives a mowed appearance. Average stubble height of carpetgrass is less than 4 inches. Threeawn grasses or forbs may be abundant.

Aside from providing a record of disturbance, burning history also described some indicator plant values for forest-range condition classifications. For instance, without burning during the previous 3 years, cutover muhly (Muhlenbergia expansa (DC.) Trin.) and blackberry (Rubus spp.) are "unaffected" and "undesirable" plants, whereas with burning, cutover muhly is a "decreaser" and blackberry is "moderately desirable."

\section{Schooling}

\section{Training}

A 4-day forest-range training school was conducted on the Palustris Experimental Forest in June, 1973. During the first 2 days, species identification and measurement techniques were discussed, demonstrated, and practiced. Evaluations of predetermined plots were carried out on the third day. Plot evaluations were discussed on the fourth day.

Each Forest Survey team member was given field training on actual sample plots during the 2 weeks immediately following the formal schooling. After field training, an intensive 1-day review session was held on the Experimental Forest to reinforce knowledge of species identification.

\section{Training evaluation}

Thirty-five circular $9.6 \mathrm{ft}^{2}$ plots were measured with a point frame for evaluation by the Forest Survey teams. Plot variety ranged from open longleaf pine forest with dense ungrazed bluestem grasses to sparsely vegetated loblolly pine-hardwood stands with uniola grasses (Uniola spp.), grasslikes, and browse dominating the understory.

Plot evaluation accuracy was tested by chi-square analyses (Freese, 1960). The accuracy specified was \pm one unit at one standard deviation probability. Since chi-square tests reject inaccurate measurements regardless of the source (bias, lack of precision, or both), additional tests were conducted when the allowable accuracy was exceeded. The tests determined if the inaccuracy was due to bias or lack of precision.

Herbage foliage cover accuracy appeared questionable since only $77 \%$ of the estimators met the requirements prior to bias elimination. Subsequent analyses showed bias caused inaccuracies. The inaccuracies were alleviated through additional field training. Other estimates were within acceptable accuracy; therefore, it was concluded that all participants were adequately trained for initiation of the first forest-range inventory of southwest Louisiana.

\section{Quality Control}

The period of field inventory extended from June to October, 1973. In all, 3,180 range sample plots were measured. Data collection time aver- aged 35 minutes per sample location.

Quality-control field checks during July and August assured conformance to the required accuracy specified. After bias elimination, only one test of the possible 330 (33 measurements by 10 individuals) was significantly inaccurate ("other vines" browse indicator species category). Data inspection indicated recording errors may have caused the inaccuracy since amounts appeared shifted on several plots.

A two standard deviation probability accuracy test was employed for identifying additional training needs. After bias elimination, only 23 of the possible 330 evaluations were significant (Table 1). All were from estimates of indicator species. Inaccuracies resulted from three main causes: (1) incorrect amounts estimated-43\%; (2) confusion of two or more plant species $-41 \%$; and (3) overlooked plant species-16\%. Most of the herbage inaccuracies resulted from confusion; browse mistakes were largely attributable to incorrect amounts. The most common herbage species confused were slender bluestem, panicum (Panicum spp.), and "other grass." Browse amounts most commonly incorrect were "other shrubs" and "other vines.",

\section{Conclusions}

From this test to devise a practical system to incorporate range methods into the nationwide Forest Survey program, we conclude that: (1) Basic range resources measurements can be made rapidly and accurately. (2) Range techniques can be taught to Forest Survey personnel within a relatively short period. Training must be intensive and well organized. (3) Species identification, cover measurements, and supplementary livestock information can be taken yearlong in the South. But, if grazing has been sufficient to remove recognizable vegetation, a relatively short period during later winter and early spring may present insurmountable problems. Except for heavy grazing situations, however, measurements would be acceptable. (4) Range sampling techniques described do not disturb the vegetation, site, or forest ecology. (5) Periodic quality control checks assure collection of reliable inventory information and serve to identify additional training needs. (6) Range resource measurements can provide a sound addition to the Forest Survey program.

\section{Literature Cited}

Blaisdell, J. P., V. L. Duvall, R. W. Harris, R. D. Lloyd, and E. H. Reid. 1970. Range 
research to meet new challenges and goals. J. Range Manage. 23:227-234.

Campbell, R. S., and J. T. Cassady. 1949. Determining forage weight on southern forest ranges. J. Range Manage. 2:30-32.

Dyksterhuis, E. J. 1949. Condition and management of range land based on quantitative ecology. J. Range Manage. 2:104-115.
Freese, F. 1960. Testing accuracy. Forest Sci. $6: 139-145$.

Grelen, H. E., and V. L. Duvall. 1966. Common plants of longleaf pinebluestem range. U. S. Dep. Agr., Forest Serv. Res. Note SO-23. 96 p. South. For. Exp. Sta., New Orleans, La.

Morris, M. J. 1973. Estimating understory plant cover with rated microplots. U. S. Dep. Agr., Forest Serv. Res. Pap. RM-104. 12 p. Rocky Mt. Forest and Range Exp. Sta., Fort Collins, Colo.

Reppert, J. N., R. H. Hughes, and D. A. Duncan. 1963. Herbage yield and its correlation with other plant measurements. p. 15-21. In Range Research Methods. U.S. Dep. Agr. Misc. Pub. 940. 